Journal of Community Based Environmental Engineering and Management, 2020, Vol. 4, No. 1: 15-24

\title{
DESIGN OF CENTRALIZED WASTEWATER SEWERAGE SYSTEM IN SMALL LENGKANG ISLAND, BATAM CITY, INDONESIA
}

\author{
Yosef Adicita $^{1}$, I Wayan Koko Suryawan, ${ }^{*}$, Muhammad Rizki Apritama ${ }^{1}$ \\ ${ }^{1)}$ Department of Environmental Engineering, Faculty of Technology, Universitas Universal, Indonesia \\ ${ }^{2)}$ Department of Environmental Engineering, Faculty of Infrastructur Planning, Universitas Pertamina, \\ Indonesia
}

\begin{abstract}
One of the small islands within the Indonesia-Singapore border is Lengkang Island. Wastewater collection infrastructure services on Lengkang Island need to be assessed to improve Sustainable Development Goals (SDGs), where access to wastewater services must reach 100\%. The purpose of this study is to determine the existing conditions of wastewater management and to plan a centralized wastewater sewerage system on Lengkang Island involving the community. The existing condition shows that all residents channel wastewater into the sea. Only a few houses have toilets, semi-permanent houses on land. Non-permanent houses built on the sea do not have latrines, where stools are dumped directly into the sea. Tripikon-S is one way to overcome the problem of impermanent homes that do not have latrines. Latrine does not provide a solution to the effects of eutropication. Centralized wastewater collection system and wastewater treatment is one way to overcome this. The results of the planning of wastewater collection systems using PVC pipes mentioned the pipe diameter between $32 \mathrm{~mm}-60 \mathrm{~mm}$, with a speed of $0.3 \mathrm{~m} / \mathrm{sec}-1.31 \mathrm{~m} / \mathrm{sec}$. With this centralized wastewater sewerage system infrastructure, community participation is expected to increase environmentally friendly development.
\end{abstract}

Kata kunci: sewerage system, small island, wastewater

\section{Introduction}

Riau Islands Province is one of the provinces in Indonesia that gives islands, which means the total sea area is more than the total sea area (Ginting, 2016). One of the cities in the Riau Islands Province is Batam City which consists of Rempang Island, Batam Island, Galang Island, Tonton Island, Nipah Island, and Galang Baru Island and small islands located in the Singapore Strait and the Malacca Strait. Based on Law

${ }^{*}$ Corresponding Author:

E-mail: i.suryawan@universitaspertamina.ac.id

Received: 24 February 2020

Revised : 11 March 2020

Acccepted: 13 March 2020
Number 27 of 2007 concerning Management of Coastal Areas and Small Islands, that is, an island which has an area of less than or equal to $2000 \mathrm{~km} 2$ and its ecosystem. Environmental pollution due to the disposal of wastewater and feces is often not supported by the provision of environmental sanitation infrastructure (Lalasati and Hadi, 2019). Realizing environmental sanitation infrastructure is supported by the 1000-100 Movement that answers the challenges of the Sustainable Development Goals (SDGs) in accessing domestic wastewater treatment by $100 \%$. Infrastructure development in the sewerage system is one of the efforts to increase 
the standard of living of the people and decrease the city without slums.

Planning for domestic wastewater management, both latrines and non-latrines, is regulated through Minister of Public Works and Public Housing Regulation No. 04/2017 regarding the Implementation of Domestic Wastewater Management Systems. The regulation does not specify specific planning areas such as small islands like Lengkang Island.

Macrozoobenthos in the waters of Lengkang Island showed that there were 3 phyla, 5 classes, 17 families with 19 species with abundance values between 3317.5 - $3809.5 \mathrm{ind} / \mathrm{m}^{3}$ (Agustinus et al., 2013). The most feared environmental impacts of improper disposal of wastewater are species dying and biodiversity loss. The death of species can occur due to explosion of algae populations or commonly called eutropication. Eutropication can be caused by nutrient content in wastewater (Suryawan et al., 2019a; Suryawan et al., 2020). Domestic wastewater treatment that can be applied such as constructed wetland and Anaerobic Baffled Reactor (ABR). Contructed wetland can use plants such as Cattail (Hidayah and Aditya, 2010), Cyperus Papyrus (Suprihatin, 2014), and Eichhornia crassipes (Suryawan, 2018). Whereas ABR can utilize bulkhead media as a medium for growing microorganisms and degrades pollutants from wastewater (Suryawan et al., 2019b).

Increasing efforts to channel wastewater is one way to increase community participation through the provision of infrastructure facilities. According to Dupai et al. (2019), this is one factor not a proactive community in development. Ikemi, (2017) states that control and management of community compliance such as water supply, sewage treatment and waste disposal are not provided properly so good planning is needed.

This article was written to find out the existing condition of wastewater management carried out by the community on Lengkang Island. In addition, a centralized wastewater distribution system was designed on Lengkang Island.

\section{Design Criteria}

The planned wastewater delivery system is a centralized wastewater delivery system, where all wastewater produced is channeled to a place and treated collectively. This system is used because the onsite system cannot be implemented due to limited land and inadequate land conditions as a result of the high population density sticks on Lengkang Island. The planning data used in this study are:

a. Primary data is a field observation of the number of houses and the current condition of wastewater treatment. In the observation also carried out measurements of the elevation of the field using GPS.

b. Secondary data obtained from the relevant agencies in the form of population data

In planning the wastewater distribution system used the calculation of the discharge which consists of:

Qr $=$ Water demand $\times$ population number $\times 0.7$

$\mathrm{q}_{\mathrm{md}}=\mathrm{F}_{\text {peak }} \times \mathrm{Qr}$
$\mathrm{Qpp}=5 \times \mathrm{P}^{0.5} \times \mathrm{qmd}$

where: 
0.7 = tipical the values required in the Detailed

Engineering Planning Guide Service Sub-

system and Collection Sub-system

$\mathrm{Qr}=$ average discharge of wastewater $(\mathrm{L} / \mathrm{sec})$;

$\mathrm{F}_{\text {peak }}=$ peak-day factor

$\mathrm{P}=$ total population (thousands of capita);

$\mathrm{q}_{\mathrm{md}}=$ maximum discharge days unit discharge

water $(\mathrm{L} / \mathrm{sec})$

Qpp = peak discharge design of parcel pipe

$(\mathrm{L} / \mathrm{sec})$

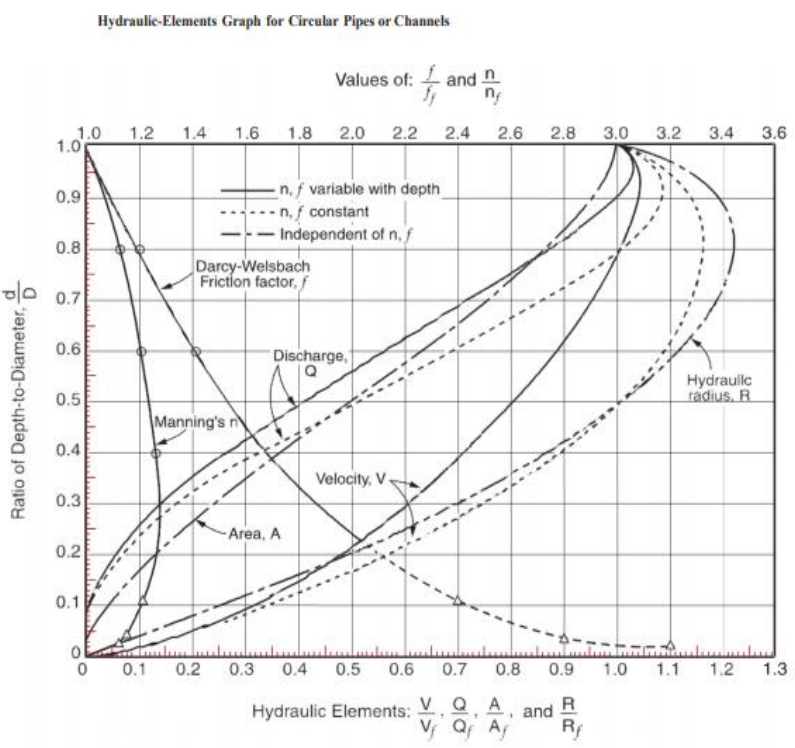

Gambar 1. Hydraulics Elements for circular cross-section of sewerage (Qasim, 1994)

The calculation of the dimensions of the pipeline in planning is based on the Manning formula:

$Q=\frac{1}{n} R^{2 / 3} S^{\frac{1}{2}} A$

Where $\mathrm{Q}$ is the discharge, $\mathrm{R}$ is the hydraulic radius, $\mathrm{S}$ is the slope, and $\mathrm{A}$ is the crosssectional area. The equation for field slope and pipe slope:

$S=\frac{\Delta H}{L}$
In this planning PVC pipes are used as conduits. Where $\mathrm{n}$ is for PVC pipe roughness in BOOK A A Detailed Technical Planning Guide for Service Sub-system and Sub-system for Raising the Roughness Coefficient of pipe (n) PVC is $0.002-0.012$. To determine the diameter of a pipe using the area equation as in equation 6 .

$A=\frac{1}{4} \pi D^{2}$

The velocity equation when the pipe is full as in equation 7 .

Vfull $=\frac{1}{n} S^{1 / 2} 0,397 D^{2 / 3}$

The velocity of drainage in the wastewater delivery system must be within certain speed limits. The minimum speed is based on the drainage ability to provide the channel's selfrinsing power against deposits. To prevent organic deposition, a minimum speed of 0.3 $\mathrm{m} / \mathrm{sec}$ is used. The design of wastewater systems for small scale also uses minimum velocity criteria of $0.3 \mathrm{~m} / \mathrm{sec}$ (Harindi and Kamil, 2010; Otis and Mara, 1985). The maximum speed is based on the ability of the channel to the possibility of scouring that occurs by flow containing coarse particles. To prevent scouring, the maximum allowable speed is around 3.0 $\mathrm{m} / \mathrm{sec}$ according to the Detailed Engineering Planning Guide for the Service Sub-system and the Collection Sub-system. The slope in this plan does not have special criteria because it considers sufficient pressure to drain wastewater by gravity.

\section{Result and Discussion}

\section{Existing Condition}

Based on the results of a survey of 146 existing housing units on Little Lengkang Island, only 26 
of them were built on land. The rest of the houses inhabited by residents are houses built above the sea or commonly called stilt houses (Figure 2). Almost all houses on Lengkang Island are built in semi-permanent and nonpermanent types. The type of settlement will

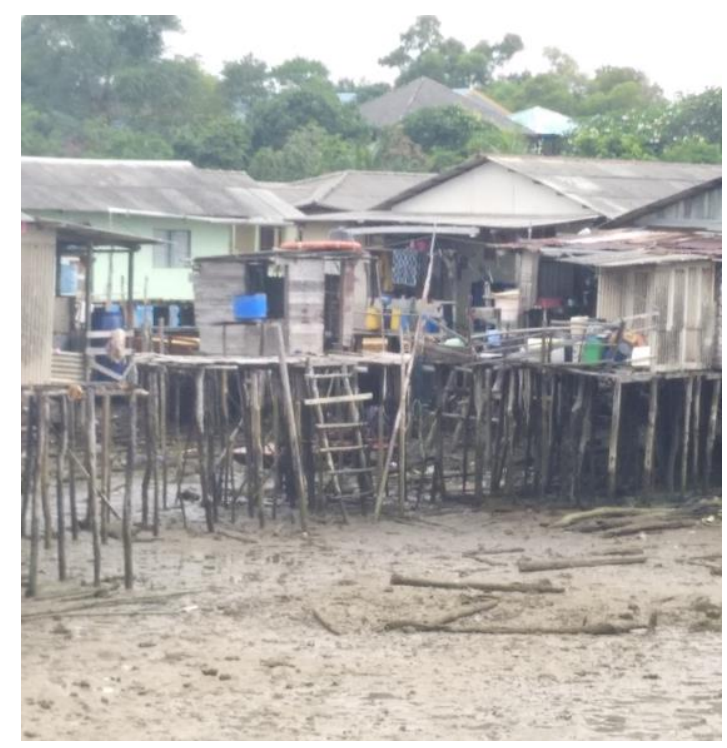

Figure 2. The Condition of Non Permanent Houses on Lengkang Island

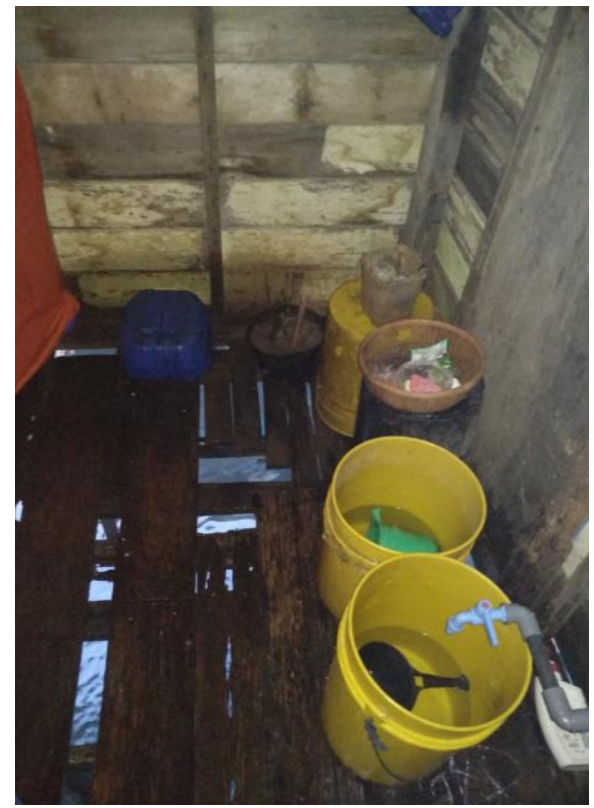

Figure 3. Examples of Simple Latrine Conditions on Lengkang Island

The results of observations on 107 house samples show black water and gray water are thrown away into the sea (simple pit sewage). affect the community's preference for household sanitation facilities, namely the type of house that has a toilet and how to dispose of waste (Lalasati and Hadi, 2019). 
the community did not know the impact that could be caused by inappropriate disposal of wastewater. Another study conducted in the Riau Islands Province, precisely on Penyengat Island, said $27 \%$ of the community also used simple pit sewage which was dumped into the sea (Lalasati and Hadi, 2019).

This domestic wastewater usually contains quite high nutrients which can lead to abundant algal growth (Suryawan and Sofiyah, 2020). Eutrophication is a complex process between growth of algal biomass as a whole but also with changes in biodiversity (Glibert, 2017).

At present there are many technologies that are suitable to be applied in the processing of feces in which are suitable for houses on stilts. Tripikon-S is one of the technologies suitable for use in stilt houses in coastal areas (Marlisa et al., 2015; Kusumaningayu, et al., 2015). However, this Tripikon-S technology still has weaknesses where the potential impact of eutropication is 2.3 $\times 10-10$ kgPO4-eq (Noor and Soewondo,
2018). The still high chance of environmental impact on the on-site system causes a centralized processing system still needs to be done.

\section{Design}

The planned wastewater delivery system is a centralized system consisting of line $\mathrm{x}$ and line y. The residential area is divided into 7 residential areas. The housing area is housing $\mathrm{A}$, B, C, D, E, F, and G. The design of the wastewater collection system can be seen in Figure 2. The calculation for parcel discharge is carried out by considering the service area for each line. In calculating the Qr, the need for water used is $120 \mathrm{~L}$ /person.day. The need is used because the small island of Lengkang is still included in the administrative area of Batam City, based on SNI 19-6728.1-2002 states that the use of water in urban areas is 120 $\mathrm{L} /$ person/day. Qpp is the total debit discharged by each house. Qpp calculation results of each house can be seen in Table. 1 .
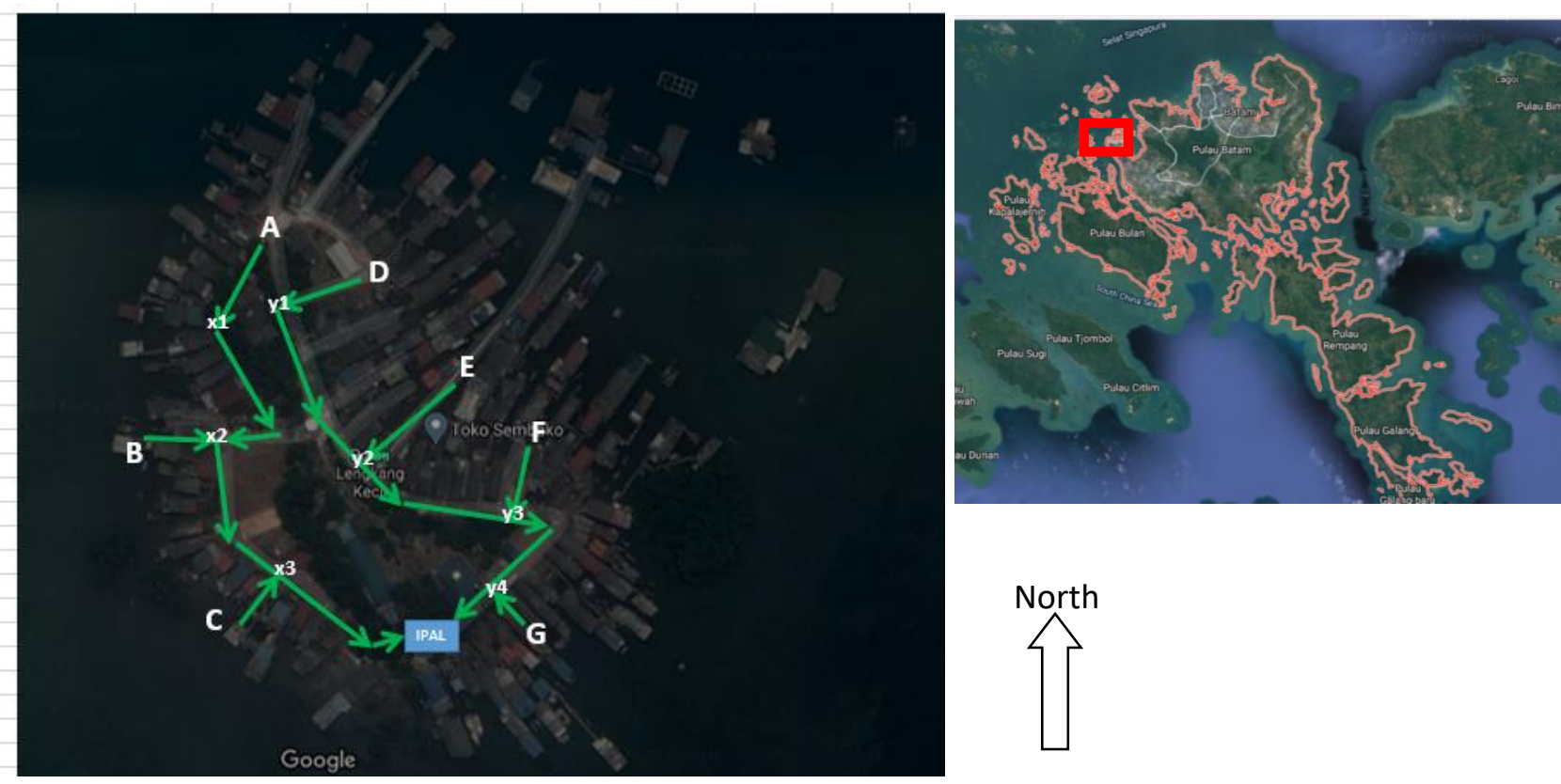

Figure 4. Map of Centralized Wastewater Sewerage System Planning in Lengkang Island. 
Table 1. Qpp calculation results for each housing

\begin{tabular}{|c|c|c|c|c|}
\hline \multirow{2}{*}{ Housing } & \multirow{2}{*}{$\begin{array}{l}\text { Number } \\
\text { of house }\end{array}$} & Qr & $\mathbf{q}_{\mathbf{m d}}$ & $\mathbf{Q}_{\mathbf{p p}}$ \\
\hline & & $\mathrm{L} / \mathrm{s}$ & $\mathrm{m}^{3} / \mathrm{s}$ & $\mathrm{m}^{3} / \mathrm{s}$ \\
\hline \multicolumn{5}{|c|}{ Line $\mathrm{X}$} \\
\hline A & 21 & 0.20 & 0.00018 & 0.00034 \\
\hline B & 15 & 0.15 & 0.00013 & 0.00021 \\
\hline $\mathrm{C}$ & 16 & 0.16 & 0.00014 & 0.00023 \\
\hline \multicolumn{5}{|c|}{ Line $\mathbf{Y}$} \\
\hline $\mathrm{D}$ & 15 & 0.15 & 0.00013 & 0.00021 \\
\hline $\mathrm{E}$ & 25 & 0.25 & 0.00022 & 0.00045 \\
\hline $\mathrm{F}$ & 23 & 0.23 & 0.00020 & 0.00040 \\
\hline G & 31 & 0.31 & 0.00027 & 0.00063 \\
\hline
\end{tabular}

The length of the measured path (L) is obtained based on observations. The value of $\Delta \mathrm{H}$ is determined based on the consideration of the field slope. Field slope tends to decrease from north to south. Discharge calculation results for each path can be seen in Table 2 .

To get the value of the diameter of the pipe installed in the channel and check the design criteria for speed the calculation is done.

Table 2. Qpp calculation results for line and slope line

\begin{tabular}{ccccc}
\hline \multirow{5}{*}{ Line } & $\mathbf{L}$ & Qpp line & $\Delta \mathbf{H}$ & $\mathbf{S}$ \\
\cline { 2 - 5 } & $\mathbf{m}$ & $\mathbf{m}^{3} / \mathbf{s}$ & $\mathbf{m}$ & $\mathbf{m} / \mathbf{m}$ \\
\hline \multicolumn{5}{c}{ Line $\mathbf{X}$} \\
\hline $\mathrm{x} 1-\mathrm{x} 2$ & 87 & 0.00034 & 0.5 & 0.005747 \\
\hline $\mathrm{x} 2-\mathrm{x} 3$ & 83 & 0.00055 & 0.5 & 0.006024 \\
\hline $\mathrm{x} 3-\mathrm{IPAL}$ & 74 & 0.00078 & 0.5 & 0.006757 \\
\hline & & Line $\mathbf{Y}$ & & \\
\hline $\mathrm{y} 1-\mathrm{y} 2$ & 101 & 0.00014 & 1 & 0.009901 \\
\hline $\mathrm{y} 2-\mathrm{y} 3$ & 84 & 0.00026 & 0.5 & 0.005952 \\
\hline $\mathrm{y} 3-\mathrm{y} 4$ & 62 & 0.00034 & 0.5 & 0.008065 \\
\hline $\mathrm{y} 4-\mathrm{IPAL}$ & 25 & 0.00055 & 0.5 & 0.02 \\
\hline
\end{tabular}

The results of the planning calculations can be seen in Table 3 and Table 4. Examples of calculations are given for lines x1-x2.

Data :

$$
\begin{array}{ll}
\text { Qpp } & =0.00034 \mathrm{~m}^{3} / \mathrm{sec} \\
\Delta \mathbf{H} & =0.5 \mathrm{~m} \\
\mathbf{S} & =0.005747 \mathrm{~m} / \mathrm{m}
\end{array}
$$

Calculation:

The $\mathrm{d} / \mathrm{D}$ is 0.8 , based on the Hydraulic Elements for Circular Sewer graph (Figure 1.), the Qpp / Qfull is 0.975 . The calculation steps are as follows:

a. Calculation of $\mathrm{Q}_{\text {full }}\left(\mathrm{m}^{3} / \mathrm{s}\right)$

$$
\begin{aligned}
Q_{\text {full }} & =Q_{\text {peak }} /\left(Q_{\text {peak }} / Q_{\text {full }}\right) \\
& =0.0003 \mathrm{~m}^{3} / \mathrm{s} / 0,975 \\
& =0.00035 \mathrm{~m}^{3} / \mathrm{s}
\end{aligned}
$$

b. Calculation of theoretical diameter and installed diameter

$$
\begin{aligned}
& 0.00035 \mathrm{~m}^{3} / \mathrm{s}=\frac{0,3117}{0,01} \times \mathrm{D}^{8 / 3} \times 0,005747^{1 / 2} \\
& \mathrm{D}=0.0363 \mathrm{~m} \\
& \mathrm{D} \text { installed }=48 \mathrm{~mm}
\end{aligned}
$$

c. Calculation of $Q$ full check $\left(\mathrm{m}^{3} / \mathrm{s}\right)$ from theoretical diameter $(\mathrm{mm})$ utilizing equation (4).

$Q_{\text {full }} \quad=0.00072 \mathrm{~m}^{3} / \mathrm{s}$

d. Calculating $\mathrm{Q}_{\text {peak }} / \mathrm{Q}_{\text {full }}$ check

$$
\begin{aligned}
& =0.00034 \mathrm{~m}^{3} / \mathrm{s} / 0.00072 \mathrm{~m}^{3} / \mathrm{s} \\
& =0.5
\end{aligned}
$$

e. Determine $d / D$ check using $Q_{\text {peak }} / \mathrm{Q}_{\text {full }}$ check graph, which is 0.5 . Using graph in Fig. 1, it can be determined that $d / D$ check value is 0.6 .

f. Calculating $A_{\text {peak }}\left(\mathrm{m}^{2}\right)$

Determine wet cross sectional area (Fig. 5) in peak condition with following method: 


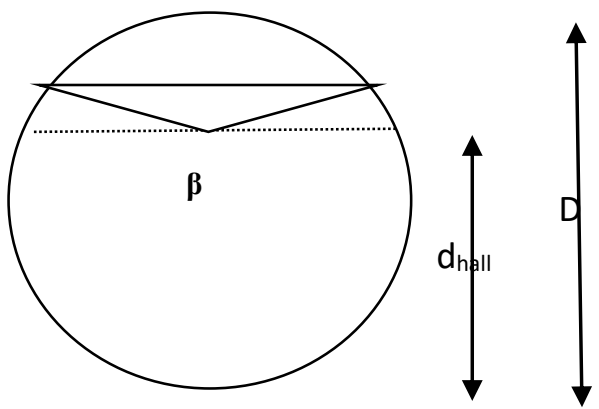

Figure 5. Variables in the Manning equation of partial gravity flow

$$
\begin{aligned}
\mathrm{r} & =0.024 \mathrm{~m} \\
\mathrm{~d}_{\text {hall }} & =\mathrm{d} / \mathrm{D} \times \text { Dinstalled } \\
& =0.6 \times 0.048 \mathrm{~m} \\
& =0.029 \mathrm{~m} \\
\mathrm{t} & =\mathrm{d}-\mathrm{r} \\
& =0.029 \mathrm{~m}-0.024 \mathrm{~m} \\
& =0.0048 \mathrm{~m} \\
\mathrm{t} / \mathrm{r} & =0.20 \\
\alpha & =2 \arccos \mathrm{t} / \mathrm{r} \\
& =2 \arccos 0.20 \\
\beta & =156.93^{\circ} \\
& =360^{\circ}-156.93^{\circ} \\
& =203.07^{\circ}
\end{aligned}
$$

\begin{tabular}{|c|c|c|c|c|c|c|c|c|c|c|}
\hline \multirow[t]{2}{*}{ Line } & Qpp & \multirow{2}{*}{$\begin{array}{c}\mathrm{d} / \mathrm{D} \\
\text { rencana }\end{array}$} & \multirow{2}{*}{$\begin{array}{l}\mathbf{Q p p} / \\
\mathbf{Q} \text { full } \\
\text { rencana }\end{array}$} & $Q$ full & \multirow[t]{2}{*}{$\mathbf{n}$} & \multirow{2}{*}{$\begin{array}{c}\begin{array}{c}\text { D } \\
\text { calculated }\end{array} \\
\mathbf{m} \\
\end{array}$} & \multirow{2}{*}{$\begin{array}{c}\text { D } \\
\text { installed } \\
\mathrm{mm} \\
\end{array}$} & \multirow{2}{*}{$\begin{array}{l}\begin{array}{l}Q \text { full } \\
\text { chek }\end{array} \\
\mathbf{m}^{3} / \mathbf{s} \\
\end{array}$} & \multirow{2}{*}{$\begin{array}{c}\text { Qpeak/ } \\
\text { Qfull chek }\end{array}$} & \multirow{2}{*}{$\begin{array}{r}\text { d/D } \\
\text { chek }\end{array}$} \\
\hline & $\mathbf{m}^{3} / \mathbf{s}$ & & & $\mathbf{m}^{3} / \mathbf{s}$ & & & & & & \\
\hline \multicolumn{11}{|c|}{ Line $X$} \\
\hline$x 1-x 2$ & 0.0003 & 0.80 & 0.975 & 0.00035 & 0.01 & 0.0363 & 48 & 0.00072 & 0.5 & 0.60 \\
\hline$x 2-x 3$ & 0.0005 & 0.80 & 0.975 & 0.00056 & 0.01 & 0.0430 & 48 & 0.00074 & 0.7 & 0.81 \\
\hline x3-IPAL & 0.0008 & 0.80 & 0.975 & 0.00080 & 0.01 & 0.0479 & 60 & 0.00141 & 0.6 & 0.68 \\
\hline \multicolumn{11}{|c|}{ Line $Y$} \\
\hline y1-y2 & 0.0001 & 0.80 & 0.975 & 0.00014 & 0.01 & 0.0232 & 32 & 0.00032 & 0.4 & 0.55 \\
\hline y2-y3 & 0.0003 & 0.80 & 0.975 & 0.00027 & 0.01 & 0.0328 & 42 & 0.00051 & 0.5 & 0.60 \\
\hline y3-y4 & 0.0003 & 0.80 & 0.975 & 0.00035 & 0.01 & 0.0342 & 48 & 0.00085 & 0.4 & 0.55 \\
\hline y4-IPAL & 0.0005 & 0.80 & 0.975 & 0.00056 & 0.01 & 0.0343 & 48 & 0.00134 & 0.4 & 0.55 \\
\hline
\end{tabular}

g. Calculating $\mathrm{V}_{\text {peak }}(\mathrm{m} / \mathrm{s})$

$$
\begin{aligned}
\mathrm{V}_{\text {peak }} & =\mathrm{Q}_{\text {pp }} / \mathrm{A}_{\text {peak }} \\
& =0.00034 / 0,0011 \\
& =0.30 \mathrm{~m} / \mathrm{s} \text { (suitable) }
\end{aligned}
$$

h. Calculating $\mathrm{V}_{\text {full }}(\mathrm{m} / \mathrm{s})$

$$
\begin{aligned}
\mathrm{V}_{\text {full }} & =\mathrm{v}_{\text {peak }} /\left(\mathrm{Q}_{\text {pp }} / \mathrm{Q}_{\text {full }}\right) \\
& =0.30 / 0,5 \\
& =0.63 \mathrm{~m} / \mathrm{s} \text { (suitable) }
\end{aligned}
$$

Table 3. The results of the diameter calculation in the centralized wastewater sewerage system 
Table 4. The results of the calculation of speed in a centralized wastewater sewerag system

\begin{tabular}{|c|c|c|c|c|c|c|c|c|c|c|c|}
\hline \multirow{2}{*}{ Line } & $\mathbf{r}$ & d hall & $\mathbf{t}$ & $\mathbf{t} / \mathbf{r}$ & $\alpha$ & $\boldsymbol{\beta}$ & $\begin{array}{c}\text { A } \\
\text { juring }\end{array}$ & $\begin{array}{c}\mathbf{A} \\
\text { triangle }\end{array}$ & Apeak & Vpeak & Vfull \\
\hline & $\mathbf{m}$ & m & m & $\mathbf{m} / \mathbf{m}$ & 0 & 0 & $\mathbf{m}^{2}$ & $\mathbf{m}^{2}$ & $\mathbf{m}^{2}$ & $\mathrm{~m} / \mathrm{sec}$ & $\mathrm{m} / \mathrm{sec}$ \\
\hline \multicolumn{12}{|c|}{ Line $X$} \\
\hline$x 1-x 2$ & 0.0240 & 0.0288 & 0.0048 & 0.20 & 156.93 & 203.07 & 0.00102 & 0.00011 & 0.00113 & 0.30 & 0.63 \\
\hline$x 2-x 3$ & 0.0240 & 0.0389 & 0.0149 & 0.62 & 103.37 & 256.63 & 0.00129 & 0.00028 & 0.00157 & 0.35 & 0.47 \\
\hline x3-IPAL & 0.0300 & 0.0408 & 0.0108 & 0.36 & 137.80 & 222.20 & 0.00174 & 0.00030 & 0.00205 & 0.38 & 0.69 \\
\hline \multicolumn{12}{|c|}{ Line $Y$} \\
\hline y1-y2 & 0.0160 & 0.0176 & 0.0016 & 0.10 & 168.52 & 191.48 & 0.00043 & 0.00003 & 0.00045 & 0.30 & 0.71 \\
\hline y2-y3 & 0.0210 & 0.0252 & 0.0042 & 0.20 & 156.93 & 203.07 & 0.00078 & 0.00009 & 0.00087 & 0.31 & 0.59 \\
\hline y3-y4 & 0.0240 & 0.0264 & 0.0024 & 0.10 & 168.52 & 191.48 & 0.00096 & 0.00006 & 0.00102 & 0.34 & 0.83 \\
\hline y4-IPAL & 0.0240 & 0.0264 & 0.0024 & 0.10 & 168.52 & 191.48 & 0.00096 & 0.00006 & 0.00102 & 0.54 & 1.31 \\
\hline
\end{tabular}

The results of Dupai et al., (2019) research on the Kendari coastal community factors influencing environmental awareness behavior are knowledge, attitudes and behaviors while the determinants that shape clean and healthy living behaviors are infrastructure availability, stakeholder intervention, routine monitoring by stakeholders, the threat of health risks due to unhealthy behavior, and the habits of coastal communities so as to enhance the environmental health behaviors of coastal communities. Thus, with the existence of a centralized wastewater distribution system infrastructure, it is expected that the living standards of the Lengkang Island coastal community will be met.

\section{Conclusion}

The existing condition of domestic wastewater management on Lengkang Island uses a simple pit sewage system which is directly channeled to the sea. This condition will cause environmental impacts both biotic and abiotic. The planning of a centralized wastewater sewerage system requires a suitable technical study that uses a gravity system with a pipe diameter of $32 \mathrm{~mm}$ $603 \mathrm{~mm}$, with the velocity of each path of 0.3 -

\section{$1.31 \mathrm{~m} / \mathrm{sec}$.}

\section{References}

Agustinus, Y., Pratomo, A., dan Apdillah, D. (2013). Struktur Komunitas Makrozoobentos sebagai Indikator Kualitas Perairan di Pulau Lengkang Kecamatan Belakang Padang Kota Batam Provinsi Kepulauan Riau. Kepulauan Riau: Universitas Maritim Raja Ali Haji (UMRAH).

Ginting, A. M. (2016). Kendala Pembangunan Provinsi Daerah Kepulauan: Studi Kasus Provinsi Kepulauan Riau. Jurnal Politica Dinamika Masalah Politik Dalam Negeri dan Hubungan Internasional, 4(1), 49-75. Harindi, F., dan Kamil, I. M. (2010). Application of Small-Bore Sewer System in Kecamatan Jatinangor, Kabupaten Sumedang. Faculty of Civil and Environment Engineering ITB.

Hidayah, E. N., Djalalembah, A., Asmar, G. A., dan Cahyonugroho, O. H. (2018). Pengaruh Aerasi Dalam Constructed Wetland Pada Pengolahan Air Limbah Domestik. Jurnal Ilmu Lingkungan, 16(2), 155-161. 
Ikemi, M. (2017). Sanitation and income improvement by local community as sustainable participatory development. In IOP Conference Series: Earth and Environmental Science (Vol. 60, No. 1, p. 012034). IOP Publishing.

Kusumaningayu, D. A., Putri, D. W., dan Soewondo, P. (2015). The Removal of Organic Substance Using the Modified Tripikon S for The Usage in Coastal and The Swamp Areas. The Third Joint Seminar of Japan and Indonesia Environmental Sustainability and Disaster Prevention (3rdESDP-2015), 255-266.

Lalasati, N. A., dan Hadi, M. P. (2019). The characteristics of fecal disposal system in Penyengat Island, Kepulauan Riau. IOP Conference Series: Earth and Environmental Science, 314, 012014.

Marlisa, D. F., Putri, D. W., dan Soewondo, P. (2015). Modification of Tripikon-S with Bioball Addition in Artificial Black Water Treatment for Swamp and Coastal Areas. The Third Joint Seminar of Japan and Indonesia Environmental Sustainability and Disaster Prevention, 231-241.

Noor, R. T., dan Soewondo, P. (2018). Selection of Alternative Domestic Wastewater Treatment Technology with Using Life Cycle Assessment (LCA) Approach: Case Study Settlement Area of Riverbank Karang Mumus of Samarinda City, East Kalimantan. Indonesian Journal of Urban and Environmental Technology, 1(2), 164-184.

Otis, R. J., dan Mara, D. D. (1985). The design of small-bore sewer systems. Washington DC: World Bank.
Peraturan Menteri Pekerjaan Umum dan Perumahan Rakyat No. 04/2017 tentang Implementasi Sistem Manajemen Air Limbah Domestik

Qasim, S., 1994. Wastewater Treatment Plants: Planning, Design and Operation.Technomic Publishing Co., Lancaster, Pennsylvania.

Suprihatin, H. (2014). Penurunan Konsentrasi BOD Limbah Domestik Menggunakan Sistem Wetland dengan Tanaman Hias Bintang Air (Cyperus alternifolius). Dinamika Lingkungan Indonesia, 1(2), 80-87.

Suryawan, I. (2018). Fitoremidiasi COD, fosfat, dan ammonia air limbah domestik bersalinitas dengan eceng gondok (Eichhornia crassipes). Jurnal Riset Kajian Teknologi Dan Lingkungan, 1(2), 95-100.

Suryawan, I. W. K., dan Sofiyah, E. S. (2020). Cultivation of Chlorella Sp. and Algae Mix for NH3-N and PO4-P Domestic Wastewater Removal. Civil and Environmental Science Journal, 3(1).

Suryawan, I. W., Helmy, Q., dan Notodarmojo, S. (2020). Laboratory scale ozone-based post-treatment from textile wastewater treatment plant effluent for water reuse. Journal of Physics: Conference Series, 1456, 012002.

Suryawan, I., Siregar, M. J., Prajati, G., dan Afifah, A. S. (2019a). Integrated ozone and anoxic-aerobic activated sludge reactor for endek (Balinese textile) wastewater treatment. Journal of Ecological Engineering, 20(7).

Suryawan, I. W., Prajati, G., Afifah, A. S., Apritama, M. R., dan Adicita, Y. (2019b). 


\begin{tabular}{lrrr} 
Continuous & \multicolumn{2}{c}{ Piggery Wastewater } & Undang-Undang Nomor 27 Tahun 2007 tentang \\
Treatment & with Anaerobic Baffled & Pengelolaan Wilayah Pesisir dan Pulau- \\
Reactor $\quad(\mathrm{ABR}) \quad$ By Bio-Activator & Pulau Kecil \\
Effective $\quad$ Microorganisms (EM4). & \\
Indonesian Journal of Urban and & \\
Environmental Technology, 3(1), 1-12.
\end{tabular}

